\title{
Faktor Penentu Kontaminasi Bakteriologik pada Makanan Jajanan di Sekolah Dasar
}

\author{
Anton Wibawa*
}

\begin{abstract}
Abstrak
Makanan jajanan merupakan produk pengolahan makanan yang banyak dijumpai di sekitar sekolah dan dikonsumsi secara rutin oleh banyak anak usia sekolah. Selain bermanfaat makanan jajanan juga berisiko menimbulkan masalah kesehatan. Tujuan penelitian ini adalah mengetahui kontaminasi bakteriologi pada makanan jajanan serta faktor yang mempengaruhinya. Penelitian ini menggunakan disain potong lintang (Cross Sectional), dengan sumber data sekunder kegiatan pengawasan makanan dan minuman oleh Dinas Kesehatan Kabupaten Tangerang tahun 2006. Sampel diambil dari 159 Sekolah Dasar di kabupaten Tangerang. Variabel yang diamati adalah : pengetahuan, perilaku, peralatan sarana air bersih, sarana pembuangan limbah, tempat pembuangan sampah dan lokasi usaha, sedangkan variabel terikat adalah kontaminasi makanan oleh bakteri E.Coli. Hasil dari analisis pada penelitian ini menunjukan sampel makanan yang terkontaminasi sebanyak 37,1\%. Sekitar (62,9\%) berpengetahuan tidak baik, perilaku tidak baik (76,7\%), lokasi usaha tidak memenuhi syarat (53,5\%), peralatan yang digunakan tidak memenuhi syarat ( $57,2 \%)$. Fasilitas sanitasi, tempat sampah tidak memenuhi syarat (93,1\%), sarana air bersih $(75,5 \%)$ tidak memenuhi syarat, sarana pembuangan limbah $(86,2 \%)$ tidak memenuhi syarat. Pada analisis multivariat diketahui bahwa perilaku merupakan variabel murni yang mempengaruhi terjadinya kontaminasi pada makanan jajanan $(p=0,011)$ dengan nilai OR $3,2(95 \%: \mathrm{Cl})$
\end{abstract}

Kata kunci : Kontaminasi bakteriologi, makanan jajanan, sekolah dasar.

\begin{abstract}
Street food is a processed food that can be easily found around schools and consumed routinely by school children. Despite its benefit, street food pose a threatening risk toward health problems. The objective of this study is to investigate bacteriological contamination in street foods and its influencing factors. Design of this study was cross-sectional using secondary data from Health Office Tangerang District year 2006. Subjects were 159 Primary Schools in Tangerang District. Variables observed including knowledge, practice, clean water facilities, waste processing facilities, and location of vendor with $E$. coli contamination as dependent variable. Analysis of the study shows that $37.1 \%$ of street foods in the study was contaminated. Around $62.9 \%$ had poor knowledge, $76.7 \%$ had poor practice, $53.5 \%$ inappropriate location, $57.2 \%$ inappropriate utensils, inappropriate sanitation facilities (93.1\%), inappropriate clean water facilities $(75.5 \%)$, and inappropriate waste management facilities $(86.2 \%)$. The multivariate analysis shows that behaviour was the single dominant variable influencing contamination of street foods $(p=0.0011)$ with OR of $3.2(95 \% \mathrm{Cl})$.
\end{abstract}

Key words : Bacteriological contamination, street foods, primary school. 
Makanan merupakan kebutuhan dasar manusia, sehingga memerlukan prasyarat kecukupan gizi yang harus dipenuhi meliputi bergizi, terbuat dari bahan yang bermutu dan aman dikonsumsi. Persyaratan keamanan makanan merupakan salah satu kriteria yang harus dipenuhi karena mempengaruhi derajat kesehatan masyarakat. Keamanan makanan adalah kondisi dan upaya yang diperlukan untuk mencegah pangan dari kemungkinan cemaran biologis, kimia dan benda lain yang dapat mengganggu dan membahayakan kesehatan manusia. ${ }^{1}$ Penyakit bawaan makanan (food borne disease) adalah istilah yang digunakan untuk menjelaskan penyakit yang ditimbulkan oleh makanan yang terkontaminasi oleh mikroorganisme pathogen. Data penyakit akibat makanan menunjukan $80 \%$ kasus yang ada disebabkan oleh higiene pengolahan makanan yang buruk. ${ }^{1}$ Sepanjang tahun 2004, di Indonesia, terjadi 152 kali kejadian luar biasa (KLB) keracunan makanan dengan jumlah penderita mencapai 7.295 orang dan yang meninggal sebanyak 45 orang. ${ }^{2}$ Selanjutnya, dari hasil monitoring kejadian luar biasa (KLB) keracunan makanan tahun 2005, dilaporkan terjadi 184 KLB keracunan makanan dengan jumlah korban sakit 8.949 orang dan yang meninggal dunia sebanyak 49 orang. ${ }^{2}$

Makanan jajanan (street food) merupakan salah satu hasil produk dari tempat pengolahan makanan. Peranan makanan jajanan di Indonesia sangat strategis, karena banyak dijumpai di lingkungan sekitar sekolah, dan umumnya rutin dikonsumsi oleh sebagian besar anak usia sekolah. Hasil Survei Ekonomi Sosial Nasional (Susenas), menunjukan bahwa pengeluaran keluarga untuk makanan jajanan di Indonesia mencapai 18,84\% per kapita per minggu dari total pengeluaran untuk makanan dan minuman atau $10,36 \%$ dari total pengeluaran keluarga. Kontribusi makanan jajanan terhadap pemenuhan gizi juga dilaporkan cukup penting, misalnya rata-rata kebutuhan energi dan protein murid SD dapat terpenuhi oleh makanan jajanan hingga sekitar 36\% untuk energi dan 30\% untuk protein. Disamping itu, pangan jajanan juga berperan terhadap penganekaragaman konsumsi oleh masyarakat Indonesia.

Namun demikian, selain mempunyai peran yang menguntungkan dalam pemenuhan gizi, makanan jajanan ini juga berisiko untuk menimbulkan masalah kesehatan. Karakteristik epidemiologi KLB keracunan makanan, jumlah keracunan makanan di rumah tangga sebesar $39,67 \%$, di sekolah/kampus sebesar $20,11 \%$, di perayaan sebesar $15,76 \%$, di asrama sebesar 9,24\%, di kantor/pabrik sebesar 5,98\%, di hotel/restoran sebesar $2,17 \%$, di tempat umum sebesar $2,17 \%$, dan yang tidak dilaporkan dimana tempat kejadiannya sebesar $4.90 \% .{ }^{3}$ Data tersebut menunjukan bahwa angka kejadian keracunan yang berasal dari makanan jajanan masih cukup tinggi.

Hasil uji laboratorium yang dilakukan oleh Balai
POM, ${ }^{2}$ pada makanan jajanan di sekolah menunjukkan, makanan tersebut tidak memenuhi syarat karena mengandung angka lempeng total bakteri $(32,72 \%)$, sakarin $(29,01 \%)$, siklamat $(24,69 \%)$, MPN Coliform $(16,05 \%)$, Rhodamin B $(8,64 \%)$, dan formalin $(3,09 \%)$. Kontaminasi dalam pengolahan makanan selain ditentukan oleh debu dan udara, ruangan serta peralatan pengolahan makanan, juga ditentukan oleh penjamah makanan (food handler), yaitu tenaga pekerja yang menjamah makanan dari mulai mempersiapkan bahan makanan, menyimpan, mengangkut sampai menyajikan makanan. Salah satu kekurangan lain dari industri tempat pengolahan makanan adalah rendahnya tingkat pendidikan pegawainya. Hasil penelitian higiene dan sanitasi di instalasi gizi pada rumah sakit di Jakarta, menunjukan $64 \%$ pendidikan para penjamah makanan adalah tamatan SD. ${ }^{4}$

Surveilans KLB keracunan makanan di kabupaten Tangerang menunjukan, sepanjang tahun 2004 terjadi 7 kali kejadian luar biasa keracunan makanan dengan jumlah korban mencapai 944 orang, sedangkan pada tahun 2005 terjadi 2 kejadian keracunan makanan dengan jumlah korban sebanyak 104 orang. ${ }^{5}$ Padahal, pada rencana kinerja Dinas Kesehatan Kabupaten Tangerang target untuk terjadinya kejadian luar biasa (KLB) keracunan makanan adalah nol kasus. Hasil pemeriksaan laboratorium terhadap 159 sampel makanan yang diambil dari makanan jajanan sekolah di Kabupaten Tangerang, sekitar 37,1\% mengandung bakteriologik coliform atau E.Eoli, sehingga menunjukan tingkat kontaminasi makanan yang tinggi. Hal ini mengindikasikan adanya masalah kebersihan dan proses memasak makanan yang tidak higienis sehingga perlu mendapat perhatian serius.

Penelitian ini bertujuan mengetahui gambaran higiene sanitasi serta faktor-faktor yang mempengaruhi kontaminasi bakteriologik pada makanan jajanan anak sekolah di Kabupaten Tangerang tahun 2006.

\section{Metode}

Penelitian ini menggunakan disain potong lintang (cross sectional), dengan memanfaatkan data sekunder dari hasil kegiatan pengawasan makanan dan minuman yang dilakukan oleh Dinas Kesehatan Kabupaten Tangerang terhadap pedagang makanan jajanan pada sekolah dasar di Kabupaten Tangerang tahun 2006. Populasi dalam penelitian ini adalah seluruh makanan jajanan di sekolah dasar di Kabupaten Tangerang tahun 2006. Adapun jumlah seluruh sekolah dasar sebanyak 1328 buah, meliputi SD negeri, SD swasta serta Madrasah Ibtidaiyah. Besar sampel adalah makanan jajan yang diambil dari 159 sekolah dasar di Kabupaten Tangerang 2006. Jumlah tersebut melampaui ukuran sampel mimimal yang dihitung untuk disain cross sectional (90). Data yang dikumpulkan yaitu data hasil pemeriksaan bakteriologik di laboratorium sebagai variabel terikat adalah pengetahuan, 
pengamatan perilaku, fasilitas sanitasi meliputi sarana air bersih, sarana pembuangan sampah dan sarana pembuangan limbah, peralatan yang digunakan serta pengamatan lokasi usaha sebagai variabel bebas. Analisis data akan dilakukan dengan menggunakan program pengolahan data melalui beberapa tahapan analisis, yaitu: univariat, bivariat dan multivariat.

\section{Hasil}

Hasil pemeriksaan di laboratorium pada makanan jajanan menunjukan bahwa hampir dari separuh sampel makanan yang diperiksa terkontaminasi positif oleh bakteri $(37,1 \%)$. Sedangkan untuk variabel pengetahuan terlihat bahwa lebih dari separuh pedagang makanan jajanan pengetahuanya tidak baik $(62,9 \%)$. Sebagian besar pedagang makanan jajanan di sekolah dasar berperilaku tidak baik $(76,7 \%)$ dan lebih dari separuh lokasi usaha dengan kondisi bangun tidak memenuhi syarat $(53,5 \%)$. Lebih dari separuh pedagang makanan jajanan di sekolah dasar tersebut menggunakan peralatan yang tidak memenuhi syarat $(57,2 \%)$. Hampir seluruh pedagang makanan kondisi sarana pembuangan sampahnya tidak memenuhi syarat $(93,1 \%)$. Sebagian besar sarana air bersih yang ada tidak memenuhi syarat $(75,5)$ dan pembuangan limbah terlihat yang tidak memenuhi syarat $(86,2 \%)$. (Lihat Tabel 1)

\section{Identifikasi Variabel Kandidat Model Multivariat}

Untuk mengidentifikasi variabel kandidat model multivariat, dilakukan analisis bivariat. Variabel yang independen dinyatakan memenuhi kriteria kandidat model multivariat jika nilai $p \leq 0,25$. Variabel yang memenuhi kriteria tersebut adalah pengetahuan $(0,028)$; perilaku $(0,009)$; peralatan $(0,039)$; dan sarana air bersih $(0,037)$. (Lihat Tabel 2)

Pada seleksi kandidat model multivariat, maka dari variabel bebas yang mempunyai nilai p uji likelihood ratio $<0,25$ masuk menjadi kandidat model. Adapun variabel-variabel yang diikutsertakan dalam analisis multivariat adalah: peralatan, sarana air bersih, perilaku dan pengetahuan. Hasil analisis regresi logistik ganda dengan menggunakan metode enter, yaitu semua variabel bebas dimasukan secara bersamaan, maka dilakukan eliminasi terhadap variabel bebas berdasarkan hasil uji $p$ Wald. Variabel bebas yang pertama dihilangkan adalah variabel sarana air bersih dengan nilai $p=0,626$ lalu dari pemodelan selanjutnya variabel yang dikeluarkan adalah peralatan dengan nilai $p=0,383$ dan dari pemodelan yang terakhir, variabel yang dikeluarkan adalah pengetahuan dengan nilai $p=0,200$. Dengan demikian, maka hasil akhir untuk model analisis multivariat adalah perilaku. Perilaku mempunyai hubungan yang bermakna setelah dikontrol oleh semua kandidat variabel bebas. Hasil dari analisis tersebut menunjukan Rasio Odds pedagang dengan perilaku tidak baik berisiko 3,2 kali (95\% CI : 1,29-7,81)
Tabel 1. Tingkat Kontaminasi Makanan

\begin{tabular}{llll}
\hline Variabel & Katagori & N & $\%$ \\
\hline Kontaminasi & Positif & 59 & 37,1 \\
Pengetahuan & Tidak baik & 110 & 69,2 \\
Perilaku & Tidak baik & 122 & 76,7 \\
Lokasi Usaha & Tak memenuhi syarat & 85 & 53,5 \\
Peralatan & Tak memenuhi syarat & 91 & 57,2 \\
Tempat Sampah & Tak memenuhi syarat & 148 & 93,1 \\
Sarana Air Bersih & Tak memenuhi syarat & 120 & 75,5 \\
Sarana Pembuangan Limbah & Tak memenuhi syarat & 137 & 86,2 \\
\hline
\end{tabular}

Tabel 2. Analisis Bivariat

\begin{tabular}{lll}
\hline Variabel & Katagori & Nilai p \\
\hline Pengetahuan & Tidak baik & 0,028 \\
Perilaku & Tidak baik & 0,009 \\
Lokasi Usaha & Tak memenuhi syarat & 0,416 \\
Peralatan & Tak memenuhi syarat & 0,039 \\
Tempat Sampah & Tak memenuhi syarat & 0,484 \\
Sarana Air Bersih & Tak memenuhi syarat & 0,037 \\
Sarana Pembuangan Limbah & Tak memenuhi syarat & 0,383 \\
\hline
\end{tabular}

Tabel 3. Analisis Multivariat

\begin{tabular}{lcccc}
\hline Variabeli & $\boldsymbol{\beta}$ & Nilai $\mathbf{p}$ & OR & 95\% CI OR \\
\hline Peralatan & 0,307 & 0,425 & 1,36 & $0,64-2,29$ \\
Sarana Air Bersih & 0,260 & 0,625 & 1,30 & $0,46-3,69$ \\
Perilaku & 0,661 & 0,269 & 1,93 & $1,60-6,25$ \\
Pengetahuan & 0,453 & 0,287 & 1,57 & $0,68=3,63$ \\
\hline
\end{tabular}

untuk terkontaminasi makanannya dibanding Rasio Odds pedagang dengan perilaku yang baik. (Lihat Tabel 3)

\section{Model Akhir}

Variabel yang memenuhi kriteria model multivariat akhir adalah perilaku dengan nilai $\mathrm{OR}=3,2$; nilai $\mathrm{p}=0,11$ dan 95\% CI OR = 1,298 - 7,811. (Lihat Tabel 4)

Dengan demikian diperoleh persamaan Regresi Logistik yang menjelaskan kontaminasi makanan jajanan sebagai berikut :

$$
\mathrm{y}=\frac{1}{1+e^{-(0,297+1,158 \text { Perilaku })}}
$$

Karena penelitian ini menggunakan disain cross sectional, maka persamaan yang dipakai adalah : Logit (kontaminasi makanan $)=0,297+1,158 *$ perilaku $=0,81$.

\section{Pembahasan}

Berdasarkan kerangka konsep dan tujuan penelitian ditemukan beberapa kendala dan keterbatasan-keterbatasan yaitu : kurangnya data umum responden seperti 
Tabel 4. Model Akhir Multivariat Akhir

\begin{tabular}{lcccc}
\hline Variabel & $\boldsymbol{\beta}$ & Nilai p & OR & 95\% CI OR \\
\hline Perilaku & 1,158 & 0,011 & 3,2 & $1,298-7,811$
\end{tabular}

tingkat pendidikan dan nilai modal usaha. Sehingga kurang memberikan gambaran kondisi sosial ekonomi responden. Merujuk pada Kepmenkes RI No. 715 Tahun 2003,6 tentang tata cara pemeriksaan sampel dan spesimen makanan di jasa boga yang termasuk dalam pemeriksaan sampel makanan adalah sampel makanan, sampel usap alat makanan, sampel usap alat masak, sampel air dan usap dubur penjamah makanan. Tetapi karena analisis dilakukan terhadap data sekunder penulis mencoba menganalisis dari data yang ada yaitu data hasil pemeriksaan bakteriologik pada makanan saja.

Sebelum melakukan pengolahan dan analisis data, terlebih dahulu dilakukan uji validitas dan reliabilitas dari pertanyaan pada kuesioner untuk mengetahui apakah kuesioner yang dipakai layak atau tidak, walaupun data yang dipakai adalah data sekunder. Hal ini penting dilakukan untuk mengetahui apakah data yang dipakai konsisten, tepat dan teliti untuk meminimasi kesalahan pengukuran. Hasil uji tersebut ternyata masih ada beberapa pertanyaan pada kuesioner yang masih belum konsisten (reliable) dan tepat, sehingga bisa menimbulkan berbagai penafsiran sehingga secara teori pertanyaan pada kuesioner yang dipakai harus dibuang supaya hasilnya bisa bermakna atau dirubah pertanyaannya sehingga tidak menimbulkan berbagai penafsiran pada responden. Kekurangan lainnya adalah sebelum melakukan pengambilan data tidak dilakukan uji kuesioner yang bertujuan untuk melihat kekurangan dari kuesioner yang ada sehingga bisa dilakukan perubahan baik dari kualitas pertanyaan ataupun dari jumlah pertanyaannya.

Masalah lain yang harus diperhatikan pada waktu pengambilan sampel adalah objek yang diteliti harus konsisten. Dalam penelitian ini ada ketidakjelasan untuk objek yang di amati apakah orang yang mengolah makanan atau yang menjajakan makanan. Kejelasan obyek yang diteliti ini sangat penting karena akan menentukan dimana dan kapan kontaminasi makanan terjadi. Kondisi yang ada tersebut, maka perlu dilakukan perbaikan metode baik dalam penyusunan kuesioner maupun tahapan-tahapan pengelolaan data serta kejelasan dalam menentukan objek serta langkah kerja, sehingga data yang diperoleh bisa dipertanggungjawabkan secara ilmiah.

Analisis data diawal pemodelan analisis multivariat, kandidat yang dimasukan adalah variabel dengan $\mathrm{p}<0,25$ dari hasil pemodelan tersebut diperoleh empat variabel yang akan masuk seleksi dalam pemodelan. Namun demikian, dari hasil eliminasi tersebut hanya satu variabel yang bermakna yaitu perilaku. Setelah itu, lalu dieksplorasi kembali dengan pendekatan confounding, namun setelah dihitung dengan menggunakan perbedaan nilai OR ternyata tidak ada perbedaan OR yang lebih dari $10 \%$ sehingga akhirnya kembali ke model awal, yaitu model tanpa confounding, sehingga variabel perilaku merupakan faktor murni untuk terjadinya kontaminasi pada makanan jajanan di sekolah dasar.

Sebanyak 159 sampel yang diperiksa di laboratorium, yang positif terkontaminasi bakteriologik sebesar $37,1 \%$. Pada pemeriksaan bakteri ini, yang dipakai sebagi indikator adalah E.coli, karena bakteri ini merupakan indikator adanya pencemaran fecal dan bakteri patogen dalam makanan dan air. Kontaminasi makanan dapat bersumber dari peralatan yang tidak bersih, bahan peralatan, cara pencucian, cara pengeringan, sterilisasi pemeliharaan serta penyimpanan alat. Selain itu, kejadian keracunan bisa terjadi karena kontaminasi silang dan kontaminasi ulang, apabila penggunaan wadah atau alat pengolahan dan penyimpanan dipakai bersama-sama. Bahkan, di negara maju pun kasus kontaminasi ulang cukup sering terjadi $(13 \%)$ dari jumlah kasus yang ada. ${ }^{7}$

Faktor lain yang dapat mempengaruhi tingkat kontaminasi adalah perilaku dan pengetahuan penjamah makanan. Hasil analisis univariat menunjukan 76,7\% pedagang makanan jajanan perilakunya tidak baik sehingga berpengaruh pada kualitas makanan, perilaku yang tidak baik apabila dilihat dari hasil pengamatan adalah pada saat menyajikan atau mengolah makanan masih sambil berbicara, selain itu sebagian besar pedagang jarang mencuci tangan dengan air bersih. Menurut Mc Swan dalam Halimatussa'diah, ${ }^{8}$ pencegahan dari penyakit yang ditularkan melalui makanan dimulai dengan personal hygiene yang baik. Selain itu, juga kebiasaan hidup yang kurang bersih dan dekatnya kontak antara limbah manusia dan sumber air minum seringkali menjadi perantara terjadinya kontaminasi ini. Depkes dalam Djaja, ${ }^{9}$ menguraikan bahwa bakteri dapat mengkontaminasi makanan melalui rambut, kulit, kuku, saluran nafas, tangan, bersin, meludah, mengatuk dan menguap. Hasil penelitian Badan Litbang Depkes di Bandung tahun 1991 menunjukan tangan penjamah makanan di restoran dan rumah makan 8,5\% tercemar Staphyloccoccus auerus dan 14\% Coli patogen.

Kebiasaan yang tidak higienis berhubungan sekali dengan tingkat kontaminasi makanan, hal ini dapat dilihat dari hasil uji bivariat yang menunjukan hubungan yang bermakna antara perilaku dengan kontaminasi makanan yaitu dengan nilai $\mathrm{p}=0,009$. Hasil dari analisis multivariat menunjukan bahwa variabel perilaku merupakan faktor penentu terjadinya kontaminasi makanan setelah dikontrol oleh variabel lainnya, dimana perilaku yang tidak baik akan menimbulkan risiko 3,2 kali untuk terjadinya kontaminasi makanan. Selain itu, dari hasil pemodelan untuk mendapatkan persamaan matematis menunjukan dari 159 
responden yang berperilaku baik maka, $81 \%$ akan terhindar dari kontaminasi bakteriologik pada makanannya.

Secara teori perilaku biasanya berkaitan erat dengan pengetahuan. Hasil dari distribusi frekuensi pengetahuan pedagang makanan jajanan berdasarkan jawaban kuesioner pada saat penyuluhan makanan, dari 159 responden yang diteliti hanya 30,8\% pedagang yang berpengetahuan baik. Salah satu keterbatasan dalam penelitian ini adalah, tidak adanya data tingkat pendidikan responden sehingga peneliti tidak dapat menganalisis hubungan pengetahuan dengan tingkat pendidikan, padahal dimungkinkan bahwa rendahnya kualitas makanan jajanan berkaitan dengan rendahnya tingkat pendidikan dan pengetahuan dari penjamah makanan yang menanganinya seperti yang diungkapkan dalam teori Green, ${ }^{10}$ bahwa pengetahuan merupakan faktor predisposisi yang dapat mendorong orang untuk berperilaku, sehingga diharapkan apabila pengetahuan seseorang baik maka perilakunya pun akan baik pula.

Survey yang dilakukan oleh Depkes dalam Marsaulina, ${ }^{11}$ menunjukkan $13,5 \%$ pedagang makanan jajanan buta huruf dan 18,8\% tidak tamat SD. Apabila melihat dari hasil uji untuk variabel pengetahuan dengan kontaminasi makanan menunjukan adanya hubungan yang bermakna. Hasil penelitian ini berbeda dengan penelitian sebelumnya yang dilakukan di tempat pengolahan makanan seperti jasa boga. Penelitian Saputra dalam Sachriani, ${ }^{12}$ di Asrama Haji Pondok Gede menunjukan pengetahuan penjamah makanan secara keseluruhan baik $(94,1 \%)$. Begitu juga penelitian Misriati, ${ }^{13}$ di katering Royale menunjukan pengetahuan penjamah makanan secara keseluruhan baik $(82,5 \%)$. Kondisi tersebut tentu berbeda dengan makanan jajanan, karena katering merupakan suatu perusahaan dengan modal yang cukup besar sehingga dimungkinkan bisa merekrut karyawan dengan latar belakang pendidikan minimal SLTA. Selain itu, jasa boga mempunyai aturan dan sanksi yang ketat dalam melaksanakan kegiatannya terutama yang berkaitan dengan aspek sanitasi serta pengawasan dari instansi terkait lebih condong ke jasa boga dibandingkan ke makanan jajanan.

Salah satu syarat tempat pengolahan makanan yang penting dan mempengaruhi kualitas higiene sanitasi makanan adalah faktor lokasi dan bangunan. Lokasi TPM harus jauh dari sumber pencemaran yang diakibatkan kondisi lingkungan yang tidak baik, seperti debu, udara, ataupun banjir. Untuk syarat fisik bangunan salah satu yang dipersyaratkan adalah kondisi dinding dan lantai dipersyaratkan harus memenuhi syarat kedap air, karena apabila tidak maka akan lembab dan menimbulkan jamur atau cendawan serta akan mengganggu estetika. Hasil analisis terhadap lokasi usaha dan bangunan tersebut maka terlihat bahwa sebagian besar lokasi belum memenuhi syarat kesehatan yaitu sebesar $53,5 \%$. Hasil pengamatan terlihat bahwa kondisi fisik bangunan terlihat tidak baik seperti kondisi dinding dan lantai. Kondisi tersebut terjadi adalah karena tidak semua tempat mempunyai dinding dan lantai sehingga dianggap kondisinya tidak baik.

Masalah lain yang berkaitan dengan sanitasi adalah mengenai peralatan yang dipakai oleh pedagang. Hasil pengamatan terhadap peralatan yang dipakai baik untuk menyajikan atau mengolah berdasarkan penampakan secara fisik termasuk ke dalam kategori tidak memenuhi syarat $(57,2 \%)$ terutama dalam penyediaan bak untuk mencuci air alat rata-rata tidak mempunyai lebih dari dua, kalaupun ada yang dipakai hanya ember dengan kondisi air yang tidak mengalir. Selain itu, semua pedagang dalam mencuci alat tidak menggunakan desinfektan, padahal desinfeksi ini berguna untuk menyucihamakan dari kuman-kuman. Hasil analisa kerawanan penyehatan di rumah makan dari penelitian yang dilakukan oleh Depkes di 8 Propinsi, ${ }^{14}$ menunjukan 32,9\% dari rumah makan yang diperiksa tercemar oleh E.coli. Padahal pada Pedoman higiene dan sanitasi makanan disebutkan bahwa standar usap alat tidak boleh mengandung E.co$\mathrm{li} / \mathrm{cm}^{2}$ permukaan alat, begitu pula pada makanan yang dihasilkan harus terbebas dari mikroorganisme. Hasil penelitian Halimatussa'diah, ${ }^{8}$ di RSUD Kabupaten Tangerang yang menunjukan kondisi peralatan yang masih kurang memenuhi syarat yaitu $71,4 \%$. Sedangkan penelitian Djaja, ${ }^{9}$ menunjukan kontaminasi E.coli pada pewadahan sebanyak $20,6 \%$. Kondisi tersebut sesuai dengan hasil analisis bivariat yang menunjukan adanya hubungan bermakna antara peralatan dengan kontaminasi makanan, dengan nilai $\mathrm{p}=0,039$.

Dalam kenyataan di lapangan kondisi peralatan yang memenuhi syarat cukup sulit untuk dicapai karena biasanya pedagang makanan jajanan dengan modal yang kecil akan menggunakan peralatan seadanya walaupun rusak asal masih kuat akan tetap dipakai. Selain itu, karena keterbatasan tenaga mereka membawa peralatan terutama untuk pencucian alat seadanya saja.

Salah satu fasilitas sanitasi yang cukup penting adalah sarana pembuangan atau sampah karena apabila sampah tidak dikelola dengan baik maka akan mengundang serangga dan tikus sebagai pembawa penyakit. Hasil analisis menunjukan bahwa kondisi tempat sampah ini hampir semua tidak memenuhi syarat yaitu $93,1 \%$, sebagian besar masalah untuk tempat sampah ini adalah tidak tertutup dan kedap air. Hasil analisis bivariat kondisi sarana pembuangan sampah apabila dihubungkan dengan kontaminasi bakteriologik pada makanan tidak menunjukkan adanya hubungan yang bermakna 0,484. Kondisi ini dimungkinkan karena walaupun tidak memenuhi syarat secara fisik tetapi sampah yang ada selalu dibuang tiap hari sehingga tidak menumpuk atau langsung dibakar setiap hari sehingga tidak menjadi perindukan serangga. Secara umum pembuangan sampah ini biasanya langsung dikumpulkan di 
tempat tertentu lalu dibakar oleh penjaga sekolah.

Sarana air bersih merupakan salah satu fasilitas sanitasi lainnya yang harus ada karena air bersih ini selain pendukung untuk perilaku higienis juga bisa dipakai sebagai pencuci peralatan sehingga air bersih ini harus tersedia dengan cukup untuk seluruh kegiatan pengelolaan makanan. Hasil analisis univariat menunjukan gambaran kondisi sarana air bersih di kantin di sekolah dasar di Kabupaten Tangerang, sebagian besar tidak memenuhi syarat yaitu sebesar $75,5 \%$. Hasil pengamatan menunjukan bahwa penyediaan air masih belum mencukupi secara kuantitas serta sebagian besar tidak menggunakan sistem perpipaan. Hasil analisis bivariat menunjukkan adanya hubungan kondisi sarana air bersih dengan kontaminasi bakteriologik pada makanan jajanan, dengan nilai $p=0,037$. Masalah kuantitas air bersih, dari hasil pengamatan di lapangan menunjukan bahwa tidak semua sekolah dasar mempunyai fasilitas air bersih. Begitu pula tidak semua SD mempunyai jalur perpipaan karena sumber air bersihnya tidak ada, kalaupun ada sumber air bersih biasanya adalah sumur gali atau pompa tangan. Air yang terlalu sedikit atau sumur terlalu jauh membuat kebersihan perorangan tidak mungkin dilakukan sebagaimana mestinya, sehingga memungkinkan untuk menularkan penyakit infeksi.

Dalam sentra makanan jajanan sarana pembuangan limbah ini dipersyaratkan sesuai dengan Kepmenkes No. 942 Tahun 2003,15 tentang pedoman persyaratan higiene sanitasi makanan jajanan dimana yang dimaksud dengan limbah salah satunya adalah air limbah dari proses pengolahan makanan yaitu dari tempat cuci dan dapur. Gambaran sarana pembuangan limbah menunjukan $86,2 \%$ tidak memenuhi syarat. Kondisi tersebut karena tidak semua tempat ada saluran pembuangan limbah dan kalaupun ada sarananya tidak tertutup sehingga bisa mengundang kehadiran lalat.

Dari analisis bivariat mengenai hubungan sarana pembuangan limbah dengan kontaminasi makanan menunjukan tidak ada hubungan yang bermakna, dengan nilai $\mathrm{p}=$ 0,383 . Pengelolaan limbah ini biasanya para pedagang yang produknya menghasilkan limbah biasanya ditampung dulu dalam ember plastik lalu setelah penuh dibuang ke WC sekolah atau dibuang ke got di sekitar sekolah.

\section{Kesimpulan}

Higiene sanitasi jajanan di sekolah dasar Kabupaten Tangerang umumnya belum memenuhi syarat. Berbagai faktor yang berhubungan dengan kontaminasi bakteriologik pada makanan jajanan adalah kondisi peralatan, sarana air bersih, pengetahuan dan perilaku pedagang. Perilaku pengelola makanan merupakan faktor penting kontaminasi bakteriologik pada makanan setelah dikontrol oleh variabel peralatan, sarana air bersih dan pengetahuan. Perilaku yang tidak baik akan meningkatkan risiko kontaminasi bakteriologik pada makanan jajanan.

\section{Saran}

Dinas Kesehatan perlu meningkatkan pembinaan, pengawasan dan inspeksi sanitasi terhadap pedagang makanan jajanan di sekolah dasar secara rutin. Perlu kerja sama pengelolaan kantin sekolah dan penyediaan fasilitas sanitasi guna meningkatkan kualitas makanan. Lomba kantin sekolah sehat diharapkan dapat memotivasi perilaku hidup bersih dan sehat pada pedagang makanan. Para pedagang makanan jajanan di SD perlu dihimpun dalam suatu sentra makanan jajanan, sehingga mudah untuk dibina dan diarahkan.

\section{Daftar Pustaka}

1. BPOM. Kasus keracunan makanan di semarang. Edisi 2004. http://www.suaramerdeka.com/harian/ 0410/11/kot05.htm, 04 April 2007.

2. BPOM. Keamanan Pangan Jajanan Anak Sekolah (PJAS). 2006. http://www.pom.go.id/e_publik/berita_aktual, 08 April 2007.

3. Depkes RI. Profil kesehatan nasional 2003. Jakarta: Depkes RI; 2005.

4. Sugiharti, Et.al. Pengetahuan dan perilaku penjamah tentang sanitasi pegolahan makanan pada instalasi gizi rumah sakit di jakarta. Media Litbang Kesehatan 2004; No. 3: XIV.

5. Depkes RI. Profil kesehatan kabupaten tangerang tahun 2004. Jakarta: Dinas Kesehatan Kabupaten Tangerang; 2005.

6. Depkes RI. Keputusan menteri kesehatan RI No. 715 tahun 2003, tentang persyaratan higiene sanitasi jasa boga. Jakarta: Depkes RI; 2006.

7. Haryeni Darma, Et.al. Studi evaluasi kondisi saniatsi pengelolaan makanan di instalasi gizi dan dapur saji kelas III RSUP DR. Hasan Sadikin Bandung. Infomatek FT-UNPAS September 2004; no. 3: 6.

8. Halimatussa'diah. Analisis kualitas makanan serta kondisi higiene dan sanitasi makanan di Rumah Sakit Umum Tangerang tahun 2006 [skripsi]. Depok: FKMUI; 2006.

9. Djaja, Made. Pengaruh jenis tempat pengelolaan makanan terhadap kontaminasi bakteri. 2003.

10. Green, L.W., et. al. Perencanaan pendidikan kesehatan sebuah pendekatan diagnostik (terjemahan). PPFKM Departemen Pendidikan dan Kebudayaan RI; 1998.

11. Marsaulina, Irnawati. Studi tentang pengetahuan, perilaku dan kebersihan penjamah makanan pada tempat umum pariwisata di DKI jakarta (TMII, TIJA, TMR). FKM-US; 1996.

12. Sachriani. Faktor-faktor yang berhubungan dengan higiene perorangan penjamah makanan jasa boga A3 di jakarta selatan [tesis]. Depok: FKM UI; 2001.

13. Misriati. Hubungan pengetahuan dan perilaku penjamah makanan dengan bakteri escherichia coli pada makanan di perusahaan di perusahaan catering PT. Tiara Royale Jakarta [skripsi]. 2000.

14. Depkes RI. Modul penyehatan makanan dan minuman untuk petugas puskesmas. Buku 6. Prinsip-prinsip pengelolaan makanan. Jakarta: Depkes RI; 1997.

15. Depkes RI. Keputusan menteri kesehatan RI no. 942 tahun 2003 tentang persyaratan higiene sanitasi makanan jajanan. Jakarta: Depkes RI; 2006. 